\title{
Human rights and modern biomedicine: problems and perspectives
}

\author{
Georgy B. Romanovskiy, Olga V. Romanovskaya* \\ Penza State University, \\ Penza, Russian Federation \\ *pgu-gpd@yandex.ru
}

\begin{abstract}
The article is devoted to the emerging threats to human rights in the context of the development of biomedical technologies, as well as to the identification of social risks requiring legal resolution in this area. It suggests a human rights model for regulating innovative methods of diagnosis and treatment. The purpose of the article is to analyze legislation in the field of modern biomedicine, genetic engineering, and related innovative technologies. A comparative legal study applied in the work made it possible to substantiate a framework model for regulating modern biomedicine. The main task of such a model is to identify risks affecting fundamental human and civil rights and freedoms. With this approach, the details of regulation are the subject of bylaws or the corresponding prescriptions of professional medical organizations. Methods. The basis of this research was formed by such research methods as analysis of legal regulation, formal legal and comparative legal methods. The main results of the study are to determine the legal links between modern biomedical technologies and the concept of personal-ized medicine. In fact, the lack of interaction of new advances in biomedicine with the basic provisions of medical care has been revealed. The article proves the need to impose restrictions on the alleged popularization of innovative technologies by persons without medical education, using them for dubious social purposes. The risks of developing updated eugenics have been outlined. The tendency of relativism in consolidating the principles of mutual relations between a person, state, and society has been identified. Conclusions. The development of biomedicine requires an adequate response from the Russian legislation, which does not yet take into account most of its achievements. This creates certain risks for human and civil rights and freedoms. The article substantiates the introduction of bans on the most ethically questionable technologies and experiments. It is proposed to expand the powers of professional medical organizations (including the transfer of some of the regulatory powers to them).
\end{abstract}

Key words: human rights, regulation, biomedicine, biomedical technologies, genome, gene diagnostics, restrictions, prohibition

Conflicts of interest. The authors declared no conflicts of interest.

The participation of the authors: Romanovskiy G.B. - scientific leadership, theoretical substantiation of the study, generalization of the results obtained, conclusion; Romanovskaya O.V. introduction, concept, scientific analysis of materials.

Article received $19^{\text {th }}$ November 2020

Article accepted $15^{\text {th }}$ January 2021

(C) Romanovskiy G.B., Romanovskaya O.V., 2021

This work is licensed under a Creative Commons Attribution 4.0 International License https://creativecommons.org/licenses/by/4.0 


\title{
For citation:
}

Romanovskiy, G.B., Romanovskaya, O.V. (2021) Human rights and modern biomedicine: problems and perspectives. RUDN Journal of Law. 25 (1), 14-31. DOI: 10.22363/23132337-2021-25-1-14-31

DOI: $10.22363 / 2313-2337-2021-25-1-14-31$

Научная статья

\section{Права человека и современная биомедицина: проблемы и перспективы}

\author{
Г.Б. Романовский, О.В. Романовская* \\ Пензенский государственный университет, \\ г. Пенза, Российская Федерация \\ *pgu-gpd@yandex.ru
}

\begin{abstract}
Аннотация. Статья посвящена возникающим угрозам прав человека в условиях развития биомедицинских технологий, а также выявлению социальных рисков, нуждающихся в правовом разрешении и появляющихся в указанной сфере, формированию правозащитной модели регулирования инновационных методов диагностики и лечения. Цель: проанализировать законодательство, определяющее отношения в области современной биомедицины, генно-инженерной деятельности, смежных инновационных технологий. Проведение сравнительно-правового исследования в заявленной сфере позволило выделить рамочную модель регулирования, нацеленную на определение рисков, затрагивающих основные права и свободы человека и гражданина. Детали регулирования - предмет подзаконных актов или соответствующих предписаний профессиональных медицинских организаций. Meтоды: основу данного исследования составили такие методы исследования как метод анализа нормативно-правового регулирования, формально-юридический и сравнительно-правовой методы. Результаты: установлена связь современных биомедицинских технологий с концепцией персонализированной медицины; подчеркивается отсутствие взаимодействия новых достижений с базовыми положениями оказания медицинской помощи; доказана необходимость введения ограничений на мнимую популяризацию инновационных технологий лицами, не имеющими медицинского образования, использующих их в сомнительных социальных целях; обозначены риски развития обновленной евгеники; показана тенденция релятивизма в закреплении принципов взаимоотношений человека, государства, общества. Bblвoдbl: показано, что развитие биомедицины требует адекватного ответа со стороны российского законодательства, не учитывающего в настоящее время большинство достижений и создающего определенные риски для прав и свобод человека и гражданина. Обосновано введение запретов на наиболее сомнительные с этической точки зрения технологии и эксперименты. Предлагается расширить полномочия профессиональных медицинских организаций (включая передачу им части регулятивных полномочий).
\end{abstract}

Ключевые слова: права человека, регулирование, биомедицина, биомедицинские технологии, геном, генная диагностика, ограничения, запрет

Конфликт интересов: Авторы заявляют об отсутствии конфликта интересов.

Информация о вкладе авторов: Романовский Г.Б. - научное руководство, теоретическое обоснование исследования, обобщение полученных результатов, заключение; Романовская О.В. - введение, концепция, научный анализ материалов. 
Дата поступления в редакцию: 19 ноября 2020 г.

Дата принятия к печати: 15 января 2021 г.

\section{Для цитирования:}

Romanovskiy G.B., Romanovskaya O.V. Human rights and modern biomedicine: problems and perspectives // Вестник Российского университета дружбы народов. Серия: Юридические науки. 2021. Т. 25. № 1. С. 14-31. DOI: 10.22363/2313-2337-2021-25-1-14-31

\section{Introduction}

Modern biomedicine attracts attention of modern people. In the conditions of information openness and rapid spread of data concerning any scientific achievement, almost everyone knows about the difficulties in genome sequencing, attempts to grow artificial organs and breakthroughs in the study of stem cells (although not everyone can imagine the specifics of the conducted experiments and their consequences; such are the disadvantages of popularizing scientific knowledge. Research at the intersection of biology and medicine has long gone beyond their own scientific scope, offering society a new era in which a complete revision of humanistic values is taking place, as well as restructuring of institutional ties.

It should not be left unnoticed that certain concerns were expressed back in the late XX - early XXI centuries, when breakthrough trends in the field of biomedicine only outlined their prospects. Francis Fukuyama, a famous futurist scientist, being a member of the Bioethics Council, created under the President of the United States, in 2002 predicted a posthuman future in which the very understanding of personality will be changed, social hierarchies will be transformed, and this, in its turn, will lead to «new speeds» of global politics (Fukuyama, 2004: 122). F. Fukuyama was not alone in this vision. A. Toffler (at about the same time) prophesied about a change in the concept of a classical family, predicting biological control over the entire period of a person's life from birth to death, as well as the end of «parental amateurism». Test-tube conception under the supervision of responsible healthcare providers should become the norm, and the family should be just a service in the employer's social package (Toffler, 2002:277). A. Toffler's idea, which is the creation of a «new» version of a person based on genetic technologies, was developed by A. Bard and J. Zoderkvist (Bard \& Zoderkvist, 2004), who proposed a new doctrine - netocracy, based on utilitarianism brought to the maximum (and on pragmatism brought to absurdity), where genocracy is the basis of social ranking. Zbigniew Brzezinski then voiced fears about the growing power of discrimination based on biological differences, predicting the role of genetics in the competitive race of political systems (Brzezinski, 2004). J. Habermas pointed to the «technicalization» of human nature, which carries its risks in constructing new principles of social life (Habermas, 2002:144).

P.D. Tishchenko, a Russian scientist, spoke about the emergence of a new phenomenon - "bio-power", within the framework of which medicine allows estab- 
lishing total control over the bodily and mental components of a person. P.D. Tishchenko identified the trends of the modern world as Lego-man and bio-mutant (Tishchenko, 2001:177). His vision of the influence of some biomedical technologies is fully confirmed. Thus, the author pointed to vaccine prevention as the basis to access social benefits. The situation with the coronavirus in 2020 is partially indicative; catastrophic rumours are spreading around the world about mass chipization to track everyone vaccinated against such a dangerous infection (and in fact to establish total control). The famous entrepreneur B. Gates is in the public eye.

\section{Legal regulation of modern biomedical technologies}

The modernization of the legal system under the influence of biomedical technologies occurs regularly, having started long before many breakthrough discoveries. A number of declarations have been adopted at the international level (for example, the Universal Declaration on the Human Genome and on Human Rights of November 11, 1997, the International Declaration on Human Genetic Data of October 16, 2003, the United Nations Declaration on Human Cloning of March 8, 2005, etc.). At the European level, the Convention for the Protection of Human Rights and Dignity of the Human Being with regard to the Application of Biology and Medicine has been adopted as well as the Convention on Human Rights and Biomedicine (Oviedo, 1997; hereinafter referred to as the Oviedo Convention). Four Additional Protocols have been adopted to this document:

- Protocol on the Prohibition of Cloning Human Beings,

- Protocol on Transplantation of Human Organs and Tissues,

- Protocol on Biomedical Research,

- Protocol on Genetic Testing for Health Purposes.

The fact, which attracts attention, is that at the international level, the subject of regulation is directly related to protecting human rights from the emerging potential threats. The legal regime of biomedical technologies (if we refer to European practice) is carried out at the level of directives and recommendations; the right of issuing such directives and recommendations is vested in various bodies. It is necessary to point at the following legal instruments:

- Directive of the European Parliament and of the Council No. 98/44 /EC of 6 July 1998 on the legal protection of biotechnological inventions,

- Directive 2004/23/EC of the European Parliament and of the Council of 31 March 2004 on setting standards of quality and safety for the donation, procurement, testing, processing, preservation, storage and distribution of human tis-sues and cells,

- Recommendation of the Committee of Ministers of the Council of Europe to member States No. CM / Rec (2016) 8 on processing personal medical data for insurance purposes, including genetic tests data (adopted by the Committee of Ministers of the Council of Europe on 26 October 2016 at the $1269^{\text {th }}$ meeting of the ministers' representatives). 
The conventions only enshrine the rules of fundamental importance that significantly affect the scope of rights and freedoms of citizens or the regulated regimes of biomedical activity that carry risks for the legal status of an individual. It is enough to refer to the text of the Oviedo Convention to see that it resolves the key issues of protecting the right to informed consent when seeking medical care, the right to privacy, and other fundamental rights affected by the provision of specialized types of medical care. The same approach is maintained in the Additional Protocols.

Reference to foreign legal acts also indicates that laws are not considered by parliamentarians as technological instructions. Pain points are identified, risks are specified - these form the basis for setting goals in the process of lawmaking. The subtleties of a particular process are the subject of bylaws or the corresponding regulations of professional medical organizations. In the United States, for example, the FDA (Food and Drug Administration) has the power to enact mandatory regulations. There is also a practice of delegating such powers to authorized medical organizations with extensive experience in a particular type of professional activity. In the USA, for example, the recommendations published by the American Society for Reproductive Medicine $(\mathrm{ASRM})^{1}$ will be mandatory for reproductive doctors. The College of American Pathologists $(\mathrm{CAP})^{2}$ develops standards for medical practice, guidelines for case management, and requirements for healthcare professionals. Due to the recognized level of organization, such instructions serve as a practical guide for many US medical doctors.

This model has its own feasibility. Firstly, the development of biomedicine is taking place by leaps and bounds. And if we try to put all aspects into the legal framework, the relevance of the adopted law will be lost as quickly as the specified branch of knowledge moves forward. Given the difficulties of parliamentary procedures, there is no need to regulate all possible relationships. Secondly, the handover to a different level of regulation ensures a prompt response to emerging threats. The relevant government department can always quickly issue a banning regulation on a risky innovation. Thirdly, it creates conditions for scientific creativity, not burdened by the rigid framework of the regulator and developing according to its own canons. Fourthly, a foundation for variability and individual approach is created. Many biomedical technologies are ambiguous and lack public consensus. The absence of law allows introducing a certain experimental regime (what is not prohibited is allowed), where only the general consent of the regulator for their use is required (but as long as it meets ethical recommendations). Fifthly, the role of the professional community, the most competent in identifying the benefits and risks of new achievements, is increasing. It is the involvement of professional associations in the regulatory process that strengthens their responsibility for the decisions they make. A responsible approach is being developed.

\footnotetext{
${ }^{1}$ American Society for Reproductive Medicine. Available from: https://www.asrm.org/ [Accessed $18^{\text {th }}$ November 2020].

${ }^{2}$ College of American Pathologists. Available from: https://www.cap.org/ [Accessed $18^{\text {th }}$ November 2020].
} 
The framework approach to regulating modern biomedicine has both supporters and opponents. The former believe that universalization will create additional opportunities for citizens; it will facilitate their access to scientific achievements. Their position is not based on the introduction of a universal ban, it is more about the liberalization of rules (Hangan, Badiu et al, 2016:68). For the sake of fairness, we will add that there are also proponents of absolute bans, which should be introduced at the international level. Thus, V.S. Ovchinsky suggests developing a convention, which envisages responsibility for some biomedical technologies (in particular, human cloning, and some experiments with human DNA) (Ovchinsky, 2005:72).

In this country, there are basic regulatory acts that determine the general legal regime of medical activity and circulation of medicines: Federal Law No. 323-FZ of November 21, 2011 On the Fundamentals of Health Protection of Citizens in the Russian Federation and Federal Law No. 61-FZ of April 12, 2010 On Circulation of Medicines. With regard to general regulation, these regulatory acts are related in some way to biomedicine. In particular, the general procedure of consent to medical intervention is mandatory both in the provision of ordinary medical services and with the help of innovative technologies. Specific issues of biomedicine are not discussed in detail in the abovementioned documents. It can only be noted that the Law On the Fundamentals of Health Protection of Citizens in the Russian Federation regulates the donation of human organs (tissues) (Article 47) and the use of assisted reproductive technologies (Article 55). Regarding the donation, will make a remark: in a number of provisions there are contradictions with the Law of the Russian Federation No. 41801 of December 22, 1992 On Transplantation of Human Organs and (or) Tissues, which led to developing the draft of the Federal Law On Human Organ Donation and Transplantation. The fate of the project is unfortunate and, in part, indicative. Almost every researcher considers the law On transplantation ... to be outdated; the draft of the new law has been published with unfailing regularity on the website of the Ministry of Health of the Russian Federation since 2014. Each time it is accompanied by a media campaign about the future modernization of the legal framework and the vector of success in transplantation medicine. There are already five or six drafts, in which the enactment date is consistently postponed. Recently, the Ministry of Health of the Russian Federation has prepared an updated draft (project ID 02/04/12-19/00098296), where the enactment date is set to be September 1, 2021, but it has not yet been submitted to the State Duma of the Russian Federation.

Of the special laws, one should point to the Federal Law No. 86-FZ of July 5, 1996 On State Regulation in the Field of Genetic Engineering. It is note-worthy that it is similar to the German law of June 20, 1990 on regulation of genetic engineering (GesetzzurRegelung der Gentechnik, abbreviated title is-GenTG). The German act, unlike the Russian one, does not cover the application of genetic engineering methods to humans. The Russian law made adjustments, indicating that gene diagnostics and gene therapy in relation to a person fall under the subject of its regulation (this adjustment was made in 2000). In Germany, there is a special law on the protection of embryo, 
which has severe requirements to gene technology that affects the human body. The Russian legislator took a simpler path, expanding the subject of regulation of the existing law, however, without considering the specifics of gene therapy and gene diagnostics in the system of medical care. Germany has the GenDG Act of July 31, 2009 on genetic testing, which takes into account the identified nuances. In particular, it banned secret tests without obtaining the consent of an individual (client or patient).

A special place is occupied by the Federal Law No. 180-FZ of June 23, 2016 On Biomedical Cell Products. Its draft was discussed several times, starting from 2011, until a voluminous document appeared, heavily loaded with technical aspects of registering the BCP (a biomedical cell product) itself. The enactment of the law was accompanied by loud reports about a breakthrough in legal regulation and a powerful basis for the development of biomedicine and investment growth. Howerev, many legal scholars expressed restrained optimism, which had certain grounds. No progress has been made, and as of November 2020, only one BCP was registered successfully. Moreover, the content of the law does not coincide with the concept of high-tech medicines used in the Decision of the Council of the Eurasian Economic Commission No. 78 of November 3, 2016 On the Registration and Examination Rules for Medicines for Medical Use (which is harmonized with the European legislation) (Merkulov, Melnikova, 2019:96). We must not forget an important postulate: any regulatory reform should not impede innovation by creating only unnecessary burdens, and without providing at least general support.

France adopted the Law No. 2004-800 of August 6, 2004 On Bioethics, but it cannot be called a system-forming document, since it introduces amendments to the already existing rules (Civil and Criminal Codes, Code of Public Health, etc.). One of the virtues of the law is the creation of an independent advisory entity on ethics, life sciences and health. At the same time, the formation procedure (in which the President of France, who appoints the chairman, the Supreme Court, ministries, and scientific community take part) determines the high authority of the decisions made.

The development of biomedicine is associated with such a concept as innovative medicine. Reference to a number of Russian policy documents - namely, the State Programme of the Russian Federation Healthcare Development No. 294 of April 15, 2014, approved by the RF Government Decree, the Strategy for Developing Medical Science in the Russian Federation for the period up to 2025 No. 2580-r of December 28, 2012, approved by the RF Government Executive Order, the Passport of the National Project Healthcare, approved by the Presidium of the RF President's Council for Strategic Development and National Projects (records No. 16 of December 24,2018$)$ - shows that key innovations are associated precisely with biomedical technologies (cellular and tissue engineering, genomic and post-genomic technologies, pharma cogenetics, DNA markers, etc).

Abroad, initiatives are put forward to pass laws on innovative medicine, where Lord M. Saatchi (Great Britain), who is considered to be among the pioneers, has suggested his own bill (appropriately named Saatchi Bill). Acquaintance with the 
bill shows that its main goal is to bring the experimental regime to the level of standard medical activity, allowing a medical worker a reasonable risk in the process of carrying out professional activities. The bill was not supported by the majority of British parliamentarians, but the course of the discussion is re-markable. Its supporters tried to expand the possibilities of using unproven technologies when treating socially significant diseases, first of all, in cancer patients (Rawlins, 2014). The opponents were inclined to conservatism, arguing that not every doctor (with a varied level of professional knowledge) can afford to experiment. This can lead to rash actions and unpredictable results (Baum, 2015). In Russia, similar initiatives were put forward in the form of drafts of the Federal Law On Experimental (Pilot) Legal Regimes in the Sphere of Biomedicine (Sergeev, Mokhov, Yavorskiy, 2019:6) and the Federal Law On Biomedical Research (Medical Experiments) in the Russian Federation (Starchikov, 2017:127), but they also did not get general support either in the professional community or in government authorities. Let us make a remark: the relevance of such legal acts is obvious, but, apparently, we should choose a different way. It is assemtial to create special legal regimes in general laws (for Russia, this is the Federal Law On the Fundamentals of Health Protection of Citizens in the Russian Federation), and not to adopt separate laws with a special subject of regulation.

\section{Law, biomedicine, personalized medicine: new social risks}

The development of biomedicine is associated with another area - personalized medicine, which, in turn, is due to the development of genomic technologies and identification of individual biological characteristics of each human organism. This will make it possible to form an individual plan not only of treatment, but al-so of social behavior designed to prevent the occurrence of predictable diseases. But serious clarifications must be made to this, too. Firstly, healthcare professionals will point out that medical treatment is a creative process, already based on an individual approach to each patient. Such arguments were publicly expressed during the implementation of standards and procedures for providing medical care stipulated in Article 37 of the Federal Law On the Fundamentals of Health Protection of Citizens in the Russian Federation. Yu.D. Sergeev and Yu.V. Bisyuk insisted on their restrictive use, exclusively when planning economic calculations with medical organizations within the framework of compulsory health insurance (Sergeev, Bisyuk, 2007:27). Moreover, it is with good reason that health care legislation uses different categories - quality, availability, satisfaction - when characterizing medical care. The interaction of all the above-mentioned factors with standards, procedures and various recommendations is based on complex principles, parameters, and indicators. By the way, the situation with the coronavirus infection has shown how rapidly treatment regimens for newly diagnosed diseases can change. At the end of October 2020, the Ministry of Health of the Russian Federation published the ninth version of the Interim Recommendations for Prevention, Diagnosis and Treatment of Coronavirus Infection (over 
six months of pandemic) $)^{3}$. And this is an illustration of a quick change in the treatment regimen, without reference to individual characteristics of an organism. Thus, the treatment of each person carries the features of an individual approach, which is the basis of personalized medicine.

Secondly, the proclamation of a new goal has not yet been conjugated with the novelties of the healthcare legislation. Let us assume that personalized medicine is more closely related to genomic technologies (including diagnostics). The most common cause of mortality in our country is the circulatory system diseases (according to the Federal State Statistics Service, about 220 thousand Russians died of them in 2019). To illustrate our point, let us take, for example, neurological diseases. The order of the Ministry of Health of the Russian Federation of November 15, 2012 No. 926n approved the Procedure for providing medical care to the adult population with nervous disorders. Also, the Ministry of Health of the Russian Federation approved Clinical Recommendations «Ischemic Stroke: Malignant middle cerebral artery infarct», where, in the description of the etiology and pathogenesis, you can find: «In young patients (18-45 years old), the most common cause of ischemic stroke is arterial dissection of cerebral vessels associated with genetically determined insufficient development of collagen structures of the vascular wall (Marfan, Ehlers-Danlos syndromes, etc.)».At the same time, medical literature emphasizes that the influence of the genotype on the risk of developing a stroke is significant precisely at a young age, since the expansion of genes changes over time, there is a versatile interaction of the genotype with external dynamic factors (Samokhvalova, 2013:157). The course of the disease occurs under the influence of genetic factors even if the patient is 70 years old (Ivanov, et al, 2010: 49). However, in Russian documents there is only a general indication of the genotype as a risk factor. Since none of the above-mentioned documents (including the standards for providing medical care) envisages genetic diagnostics, it is not covered by the Programme of State Guarantees of Providing Free Medical Care to Citizens. The minimum amount of research costs about five thousand roules (this cost is based on the pricing policy in the Penza region medical organizations), which significantly affects the patient's (and his relatives') desire to undergo additional examination. If we want to predict morbidity in the "Neurology" sphere and its dependence on genetic factors, then it is advisable to conduct a mass examination of young citizens of Russia. This will make it possible to formulate recommendations aimed at maintaining population health.

Currently, by the Order of the Ministry of Health of the Russian Federation No. 186 of April 24, 2018, a special Concept for predictive, preventive and personalized medicine has been approved. By the Decree of the Government of the Russian Federation of April 22, 2019 No. 479, the Federal Scientific and Technical Proramme for the Development of Genetic Technologies for 2019-2027 was adopted, which al-

\footnotetext{
${ }^{3}$ Ninth version of COVID-19 guidelines was published. Available from: https://minzdrav.gov.ru/news/2020/ 10/26/15277-opublikovana-devyataya-versiya-metodrekomendatsiy-po-covid-19 [Accessed $20^{\text {th }}$ November 2020].
} 
so pays special attention to the development of personalized medicine. Among the significant tasks, the formation of regulatory and legal support for using genetic technologies in biomedicine is indicated, but the realities are still negative: legislative acts are adopted spontaneously, consolidating unnecessary administrative barriers, haphazardly, without taking into account the current situation in the Russian healthcare.

Thirdly, the development of personalized medicine should be carried out precisely by specialists, while charlatans, who are trying to either parasitize on a new trend in science or use innovations for dubious purposes, should be weeded out by the professional community. This point needs developing. The situation with Angelina Jolie, who underwent a mastectomy with the removal of the ovary due to her predisposition to breast cancer, gained worldwide fame. Information about the mutation of brca1 and brca2 genes, a genetic factor of cancer, was publicized. This aroused interest not only in the system of cancer prevention using gene diagnostics, but also in making independent decisions by women about mastectomy without direct indications (just in case). The owners of the social network PrimerLife, who have received the status of a Skolkovo resident and have ambitious plans to form new principles of social interaction ${ }^{4}$, are trying to make money in the field of collecting genetic data.

This network is far from being the only one. All of them have a relatively typical principle of operation. There is an exaggerated advertisement for the independent collection of biological material, its sending to a special laboratory, where the genome is deciphered (as a rule, partially), the data is loaded and processed. According to certain parameters, a social network can produce the desired result. So, «PrimerLife» offers to issue various recommendations: from choosing diet to selecting a life partner. A social network has been created abroad to find relatives. In the United States, such a network is popular among artificially conceived children who want to find their biological parents (there is also the opposite situation: donors of biological material are looking for their children). Similar activities in many countries (Switzerland, Finland, the Netherlands, etc.) have become the reason for abandoning the principle of anonymity in reproductive technologies.

The company "23andMe", which has serious informational and financial support, has become notorious due to the fact that it was created by Anne Wojcicki, the wifeof Sergey Brin, Head of Google. Everyone is invited to independently take a genetic test and receive a different set of information services: ranging from searching for relatives and forming a family tree to determining the Neanderthal gene. Low testing costs (currently \$79) are contributing to the network's rapid expansion. But it also has serious opponents such as sectoral government authorities in the health sector, which impose restrictions on such large-scale popularization of genetic data, by

\footnotetext{
${ }^{4}$ Musienko, S. We will look for a husband or wife, focusing on genomes / Russian reporter. Available from: http://www.rusrep.ru/article/2012/03/07/genom [Accessed $12^{\text {th }}$ November 2020].

${ }^{5}$ Official website of the company. Available from: https://www.23andme.com/ancestry/ [Accessed $12^{\text {th }}$ November 2020].
} 
people without medical education, and laboratories that do not have permits to conduct the relevant research. In addition, the material sampling itself is carried out without consulting a doctor, and subsequent data calculations are also systematized using artificial intelligence (without medical supervision). Health care providers are also not very enthusiastic about such social initiatives. There are regular attempts to ban the company in some US states and countries, but the company successfully resists all the attempts (which is not surprising for a firm backed by a giant like Google). However, «23andMe» is becoming an aggregator of a large genetic database.

Fourthly, personalization of medicine and general dependence of mankind on medical data reanimate the risks of eugenics, whose «ghost» has become increasingly apparent in recent years. In a number of countries, attempts have been made to legitimize eugenic rules (or rather, their understanding at a certain historical moment). In the United States, this is the legislation on restricting immigration, adopted in the 1920s under the slogan of US President C. Coolidge «America should be for Americans $»^{6}$. In Soviet Russia, the Regulations on the People's Commissariat of Health (adopted in 1927) envisaged the implementation of such a function as «developing the issues of eugenics and racial hygiene». The eugenic society was actively developing at that time in the USSR, but after genetics had been proclaimed a bourgeois science, it was completely destroyed. Modern legal acts (international and national) put up appropriate legal barriers. The prohibition of eugenic practices is provided for by Article 3 of the Charter of Fundamental Rights of the European Union (Nice, December 7, 2000), Article 25 of the Armenian Constitution, Article III of the Section «Freedom and Responsibility» of the Basic Law of Hungary, and Article 16-4 of the French Civil Code. Russian legislation is absent from this range: it is impossible to find direct bans on selective practices in relation to a person.

These social risks are not exhaustive. Western philosophy actively participates in the process of their discussion. The proposals are varied: from introduction of absolute bans to complete liberalization of legislation and rejection of government intervention. Various theories with far-reaching consequences appear against this background. For example, R. Posner put forward the concept of «strictly not observed absolute formal prohibitions» (Posner, 2006:171), which has been subject to some criticism (Segev, 2009:239). Although the idea was related to anti-terrorism legislation, many followers see it as a universal message to the future jurisprudence. This means that a certain scientific basis is being created that calls into question the basic values in the human rights system. In other words: even those rules by which a public consensus has been developed can be adjusted depending on the current situation. Relativism in regulation and protection of human rights is substantiated. Taking into account the development of biomedicine and the expansion of knowledge in the field of Homo sapiens' nature, such an approach may lead to a revision of all the commit-

\footnotetext{
${ }^{6}$ Lombardo P. Eugenics Laws Restricting Immigration. Available from: http://www.eugenicsarchive.org/ html/eugenics/essay9text.html [Accessed $15^{\text {th }}$ November].
} 
ments achieved over the past 50-70 years in the field of human and civil rights and freedoms. Moreover, one might be concerned about the fact that it is proposed not to change the text of the main international conventions and constitutional acts, but to transform the content that is provided by the world community.

In this regard, let us pay attention to the possibility of changing the concept of constitutional legal personality of a person due to the appearance of genetically transformed organisms. The pioneer was the Chinese scientist He Jiankui, who announced the creation of a genetically modified human embryo, which was later born. For this he was subjected to universal condemnation, and in China he was also sentenced to a real term of imprisonment ${ }^{7}$. This information drew attention to various experiments on creating a human-animal chimera. The idea of creating a humanzee (humanchimpanzee) is discussed not only at the level of futurological fantasies, but also among biologists (Li, Saunders, 2005:50). The introduction of human cells into the body of animals is a routine practice. Since 2013, a large-scale project HUMAN (Health and the Understanding of Metabolism, Aging and Nutrition) has been implemented in Europe, based on the adaptation of human cells in various organs of mice and rabbits (Esteves et al. 2018:4). There have been attempts to introduce neurons into the brains of mice, but these have been abandoned due to ethical requirements. Such a mouse was even given a common name - "Mickey Mouse", with an allusion to verbal communication practices (Sherringham, 2008:771). Similar experiments are being carried out in the Russian Federation. In 2016, Rospatent (Russian Federal Service for Intellectual Property) considered the application from the institutes of the Russian Academy of Sciences for the invention of the «Method for producing cybrids with the human genome», which declared the possibility of obtaining an embryo containing $100 \%$ nuclear human genome and mitochondrial DNA of a mouse.

Of particular concern is the possibility of systematizing large volumes of personalized information in a highly sensitive area. Moreover, new technologies allow the citizens themselves to accumulate data about their health using various gadgets. At the same time, gadget developers warn that information can be redirected to the developer, accumulated in a cloud server, and then systematized (as Apple promises, impersonally and only for technical purposes to improve the service) according to some parameters. If a few years ago it was only possible to project threats, understanding that they are of science fiction nature due to the impossibility of processing a huge amount of data, now artificial intelligence allows efficient processing. The amount of information is growing exponentially. An analytical report from the Stanford University School of Medicine indicates that while 153 exabytes (one exabyte equals one billion gigabytes) of medical data were accumulated in 2013, the goal for 2020 is to process 2,314 exabytes $^{8}$.

\footnotetext{
${ }^{7}$ Yangfei Z. He Jiankui gets 3 years for illegal human embryo gene-editing. China Daily. Available from: https:// www.chinadaily.com.cn/a/201912/30/WS5e098549a310cf3e35581783.html [Accessed $20^{\text {th }}$ November 2020]. ${ }^{8}$ Stanford Medicine, 2017. Health Trends Report Harnessing the Power of Data in Health. Available from: https://med.stanford.edu/content/dam/sm/sm-news/documents/StanfordMedicineHealthTrendsWhitePaper2017. pdf [Accessed $16^{\text {th }}$ November 2020].
} 
It is necessary to understand that the accumulation of information about the health of each citizen makes it possible to formulate generalized conclusions about the state of public health. This, in turn, makes it possible to plan costs for certain health care sectors, distribute medicines (primarily those of high cost), and draw up strategic plans for the development of preventive medicine. But at the same time, it creates a certain vulnerability for the state if it does not have medicinal independence. In the event of introducing sanctions policy (which has become a kind of trend for government-to-government communication in recent decades), the refusal to supply vital medicines may become the most effective method of influence. A similar situation arises when the rights of the information aggregator are transferred to a nongovernmental organization, which will initially receive advantages when its interests merge with the main participants of the pharmaceutical market. This creates an ideal situation for establishing a monopoly on distributing medicines.

The use of gadgets in self-tracking of one's own health (or its maintenance) creates additional risks in ensuring cyber security. For example, a famous service is the Merlin.net Patient Care Network (PCN) service, which collects data from St. Jude Medicalcardiac pacemakers. A data breach would allow an unauthorized user to disable the device. As a result of this action, the patient will die of cardiac arrest. On $\mathrm{Au}-$ gust 29, 2017, the FDA (the USA) issued a special press release on the vulnerability of the implantable cardiac pacemakers and the need for additional cyber protection ${ }^{9}$.

The regulation of assisted reproductive technologies requires special attention. Listing the possibilities in this area would take more than one research article (especially with a discussion of all the arguments of supporters and opponents of certain technologies). It is already possible to edit the embryo genome, surrogate maternity with a significant number of participants (which complicates the search for biological relationship), auto-eugenics, and cryopreservation of germ cells. Each of them creates a layer of legal problems, many of which are not resolved in the legislation of our country. Moreover, it should would like to emphasize that a characteristic feature of Russian legal acts is ultimate liberalism, which has made it possible, for example, to reveal the facts of Russian women giving birth to children for export. This practice is banned even in India, which has long been imputed as a form of biological exploitation of a woman deprived of rights. Unfortunately, the pandemic has revealed that the place of developing countries in this business is now being taken by the Russian Federation. Let us remember that in June 2020, five babies were found born by surrogate mothers in Russia, intended for further shipment to China, but «stuck» due to the introduction of restrictive measures caused by the coronavirus ${ }^{10}$. Back in 2019, a stag-

\footnotetext{
${ }^{9}$ Firmware Update to Address Cybersecurity Vulnerabilities Identified in Abbott's (formerly St. Jude Medical's) Implantable Cardiac Pacemakers: FDA Safety Communication. Available from: https://www.fda.gov/ medical-devices/safety-communications/firmware-update-address-cybersecurity-vulnerabilities-identified-abbotts-formerly-st-jude-medicals [Accessed $20^{\text {th }}$ November 2020].

${ }^{10}$ Surrogate business. Babies for Chinese citizens lived in terrible conditions. Arguments and Facts. $30^{\text {th }}$ June, 2020. Available from: https://aif.ru/society/law/surrogatnyy_biznes_mladency_dlya_grazhdan_kitaya_zhili_ v_zhutkih_usloviyah [Accessed $22^{\text {th }}$ November 2020].
} 
gering number was announced: about five thousand children ${ }^{11}$ are "supplied" to China from Moscow alone every year. The legal press has repeatedly voiced (Momotov, 2019:32; Serebryakova, 2016:53) the demands to impose severe restrictions on a number of assisted reproductive technologies (at least following the example of most European countries), but only the scandal with the children in 2020 revived the forgotten discussion. Back in September 2009, A. Baranov, Russian chief pediatrician, vice president of RAMS, spoke very carefully about the importance of assisted reproductive technologies, confirming his statement with the data: $2 / 3$ of children born as a result of extracorporal fertilization suffer from serious diseases, and the women who turn to this procedure cause harm to their health ${ }^{12}$. But then, his professional opinion caused an avalanche of criticism.

\section{Conclusions}

The current state of biomedicine indicates the formation of the public agenda: natural science has presented a number of new achievements that need social assessment and legal regulation. Russian legislation lags far behind on most of the stated problems. There is lack of information, which allows unscrupulous actors to abuse the absence of bans on questionable technologies. The media regularly cover certain scandalous stories (such as, for example, the delivery of newborn babies to China from surrogate mothers), which force representatives of the official authorities and civil society institutions to look at the problem. Pointed decisions are made, but, as a rule, they do not address the essence of the problem.

The quality of legal regulation is also influenced by the long time needed to adopt a law by the state bodies. Vivid examples are modernization of legislation in the field of transplantation (which has not been moving forward for about seven years) and enactment of the law on biomedical cell products. The delay is mainly connected with the developers' desire to subject to detailed regulation the moments that could be transferred to the sub-legislative level while maintaining the general principles of legal impact. International practices show that the most relevant issues in regulating biomedical technologies are the protection of human rights (especially of vulnerable categories). This predetermines the subject of regulation of framework laws that do not go deep into the details of the processes themselves. Moreover, special sections are adopted within the framework of codified acts (often in the Civil Code).

It is necessary to enhance the role of the professional community and ethics committees. In West European countries, have been created medical associations, which have received many public functions, including the regulatory ones. The UK

\footnotetext{
${ }^{11}$ Vardanyan A. The Chinese go on baby-tours for children from Russian surrogate mothers. Komsomolskaya Pravda. $18^{\text {th }}$ December, 2019. Available from: https://www.spb.kp.ru/daily/27069/4138796/ [Accessed $18^{\text {th }}$ November 2020].

${ }^{12}$ Medicine news. $28^{\text {th }}$ September, 2009. Available from: http://medportal.ru/mednovosti/news/2009/09/28/ivf/ [Accessed 20 ${ }^{\text {th }}$ November 2020].
} 
has the experience of creating QUANGO (quasi-autonomous non-governmental organization), which is an autonomous organization combining public (by function) and private (by principles of activity) fundamentals aimed at attracting professionals to the public administration system (Romanovskaya, 2018:38). In any case, the need for professional assessment of emerging problems is constantly increasing (and in terms of biomedicine, it is increasing exponentially). Abroad, ethics committees also have a high degree of independence, which is ensured by the formation procedure (as advised by the highest government bodies) and the requirements for their composition. The information function of these committees is carried out through constant monitoring of the level of development of biomedicine and publishing regular reports that underlie the official decisions taken.

It is necessary to introduce amendments to the Federal Law On the Fundamentals of Health Protection of Citizens in the Russian Federation, which should not only determine the legal regime of certain biomedical technologies, but also align the innovations with the general rules of providing medical care, which will require a thorough analysis of all institutions of health law. Urgent prohibitions should be introduced on the most ethically questionable technologies and experiments. In particular, it is required to ban creating human-animal chimeras, genetically modified human being, auto-eugenics, and/or establish restrictions on a number of reproductive technologies (that are now characterized by extreme liberalism, which does not correlate with the general vector of protecting traditional values in our country), and manipulations with the human genome. This will require hard and thorough work on the systematic analysis of many legal institutions. Changes in health law will entail the improvement of related industries. And all these are impossible without careful discussion by the professional community, development of a unified policy, where the achievements of natural, medical and humanitarian sciences, as well as foundation of basic ethical values, will be central.

\section{References / Библиографический список}

Bard, J. \& Zoderkvist, A. (2004) Netocracy. The new power elite and life after capitalism. Translated from English by Mishuchkov V. Saint Petersburg, Stockholm School of Economics in Saint Petersburg Publ. (in Russian).

Netoкратия. Новая правящая элита и жизнь после капитализма / А. Бард, Я. Зодерквист; [пер. с англ. В. Мишучкова]. Санкт-Петербург: Изд-во Стокгольмской Школы Экономики в Санкт-Петербурге, 2004. 251 с.

Baum, M. (2015) Saatchi is right to promote medical innovation but his bill is wrong way to do it. The British Medical Journal. 350. Available from: doi: https://doi.org/10.1136/bmj.h531 [Accessed $18^{\text {th }}$ November 2020].

Brzezinski, Z. (2004) The choice: global domination or global leadership. Translated from English by Narochnitskaya E.A., Kobyakov Yu.N. Moscow, International Relations Publ. (in Russian).

Бжезинский 3. Выбор: Мировое господство или глобальное лидерство / пер. с англ. Е.А. Нарочницкой, Ю.Н. Кобякова. М.: Международные отношения, 2004. 287 с. 
Esteves, P.J., Abrantes, J. \& Baldauf, H. et al. (2018) The wide utility of rabbits as models of human diseases. Experimental \& Molecular Medicine. (50), 1-10.

Fukuyama, F. (2004) Our Posthuman Future: Consequences of the Biotechnological Revolution. Translated from English by Levin M.B. Moscow, Progress Publ. (in Russian).

Фукуяма $\Phi$. Наше постчеловеческое будущее: Последствия биотехнологической революции / пер. с англ. М.Б. Левина. М.: Прогресс, 2004. 352 с.

Habermas, J. (2002) The future of human nature. Translation from German. Moscow, Ves Mir. Publ. (in Russian).

Хабермас Ю. Будущее человеческой природы. Пер. с нем. М.: Изд-во Весь Мир, 2002. $144 \mathrm{c}$.

Hangan, T.L., Badiu, D., Vladareanu, R., Tampa, M., Georgescu, R.S. \& Bohiltea, R., et al. (2016) Assisted reproductive technology in Europe: research, legal and Ethical Aspects. GINECOeu. 12 (2), 67-70. Doi: 10.18643/gieu.2016.67

Ivanov, V.P., Vasilyeva, O.V., Polonikov, A.V., Vyalykh, E.K. \& Solodilova, M.A., et al. (2010) On the question of the genetic mechanisms of the development of vascular diseases of the brain. Scientific Notes. The online academic journal of Kursk State University. 2 (14), 4752. (in Russian).

Иванов В.П., Васильева О.В., Полоников А.В., Вяльхх Е.К., Солодилова М.А., Полякова H.B., Аниупов B.B. К вопросу о генетических механизмах развития сосудистых заболеваниях мозга // Ученые записки. Электронный научный журнал Курского государственного университета. 2010. № 2 (14). С. 47-52.

Kehrer-Sawatzki, H. \& Coope, D.N. (2007) Understanding the recent evolution of the human genome: insights from human - chimpanzee genome comparisons. Human Mutation. 28 (2), 99-130.

Li, W.-H. \& Saunders, M.A. (2005) The Chimpanzee and us. Nature. 437(7055), 50-51. Doi.org/10.1038/437050a

Merkulov, V.A. \& Melnikova, E.V. (2019) Biomedical Cell Products or High-Tech Medicines? BIOPreparations. Prevention, diagnosis, treatment. 19 (2), 94-98. (in Russian).

Меркулов В.А., Мельникова Е.В. Биомедицинские клеточные продукты или высокотехнологические лекарственные препараты? // БИОпрепараты. Профилактика, диагностика, лечение. 2019. Т. 19. № 2. С. 94-98.

Momotov, V.V. (2019) Bioethics in the Context of Legislation and Law Enforcement (Surrogacy). Lex Russica. (1), 29-39. (in Russian).

Момотов B.B. Биоэтика в контексте законодательства и правоприменения (суррогатное материнство) // Lex Russica (Русский закон). 2019. № 1. С. 29-39.

Ovchinsky, V.S. (2005) Criminology and Biotechnology. Moscow, Norma Publ. (in Russian).

Овчинский В.С. Криминология и биотехнологии. М.: Норма, 2005. 191 с.

Posner, R.A. (2006) Not a Suicide Pact: The Constitution in a Time of National Emergency. Oxford University Press. Available from: http://bookre.org/reader?file=744758 [Accessed $18^{\text {th }}$ November 2020].

Rawlins, M.D. (2014) The "Saatchi bill" will allow responsible innovation in treatment. The British Medical Journal. 348. Doi: https://doi.org/10.1136/bmj.g2771

Romanovskaya, O.V. (2018) QUANGO - a legal model for increasing the efficiency of state power. Bulletin of the Volga region Institute of Administration. 18 (5), 37-45. Doi 10.22394/1682-2358-2018-5-37-45 (in Russian).

Романовская O.B. КВАНГО (QUANGO) — правовая модель повышения эффективности государственной власти // Вестник Поволжского института управления. 2018. T. 18. № 5. C. 37-45. Doi 10.22394/1682-2358-2018-5-37-45 
Samokhvalova, V.V. (2013) Molecular genetic aspects of the development of ischemic stroke. Tavricheskiy Mediko-Biologicheskiy Vestnik. 16 (1), 157-158. (in Russian).

Самохвалова В.B. Молекулярно-генетические аспекты развития ишемического инсульта // Таврический медико-биологический вестник. 2013. Т. 16. № 1. С. 157-158.

Segev, R. (2009) Balancing, Judicial Review, and Disobedience: Comments on Richard Posner's Analysis of Anti-Terror Measures (Not a Suicide Pact). Israel Law Review. 42 (2), 234247. Doi: $10.1017 /$ S0021223700000558

Serebryakova, A.A. (2016) Problems of legal regulation of surrogate motherhood. Russian Justice. (12), 52-55. (in Russian).

Серебрякова A.A. Проблемы правового регулирования суррогатного материнства // Российская юстиция. 2016. № 12. С. 52-55.

Sergeev, Yu.D. \& Bisyuk, Yu.V. (2007) Standards of medical care: the role and significance for investigative and judicial practice. Russian judge. (4), 26-28. (in Russian).

Сергеев Ю.Д., Бисюк Ю.В. Стандарты оказания медицинской помощи: роль и значение для следственно-судебной практики // Российский судья. 2007. № 4. С. 26-28.

Sergeev, Yu.D., Mokhov, A.A. \& Yavorskiy, A.N. (2019) Pilot (experimental) legal regime for national biomedical science and practice. Medical Law. (4), 3-13. (in Russian).

Сергеев Ю.Д., Мохов А.А., Яворский А.Н. Пилотный (экспериментальный) правовой режим для отечественной биомедицинской науки и практики // Медицинское право. 2019. № 4. C. 3-13.

Sherringham, T. (2008) Mice, Men, and Monsters: Opposition to Chimera. Research and the Scope of Federal Regulation. California Law Review. 96(3), 765-800.

Starchikov, M.Yu. (2017) Grounds for exempting medical organizations from civil liability for harm caused to the life (health) of patients in the provision of medical services: theoretical provisions and judicial practice. Moscow, Infotropic Media Publ. (in Russian).

Старчиков М.Ю. Основания освобождения медицинских организаций от гражданско-правовой ответственности за вред, причиненный жизни (здоровью) пациентов при оказании медицинских услуг: теоретические положения и судебная практика.

М.: Инфотропик Медиа, 2017. 224 с.

Tishchenko, P.D. (2001) Bio-power in the age of biotechnology. Moscow, IFRAN Publ. (in Russian).

Тищенко П.Д. Био-власть в эпоху биотехнологий. М.: ИФРАН, 2001. 177 с.

Toffler, E. (2002) Future Shock. Translation from English. Moscow, AST Publ. (in Russian).

Тоффлер Э. Шок будущего: Пер. с англ. М.: АСТ, 2002. 557 с.

\section{About the authors:}

Georgy B. Romanovskiy - Doctor of Law, Full Professor, Head of the Department of Criminal Law, Penza State University; 40 Krasnaya str., Penza, 440026, Russian Federation

ORCID ID: 0000-0003-0546-2557; ResearcherID: S-7012-2016; SPIN-code: 2791-8376 e-mail:vlad93@sura.ru

Olga V. Romanovskaya - Doctor of Law, Full Professor, Head of the Department of State and Legal Disciplines, Penza State University; 40 Krasnaya str., Penza, 440026, Russian Federation

ORCID ID: 0000-0002-4563-1725; ResearcherID: C-7120-2017; SPIN-code: 5496-7700 e-mail:pgu-gpd@yandex.ru 


\section{Об авторах:}

Романовский Георгий Борисович - доктор юридических наук, профессор, заведующий кафедрой «Уголовное право», Пензенский государственный университет; 440026, Российская Федерация, г. Пенза, ул. Красная, д. 40

ORCID ID: 0000-0003-0546-2557; ResearcherID: S-7012-2016; SPIN-code: 2791-8376 e-mail:vlad93@sura.ru

Романовская Ольга Валентиновна - доктор юридических наук, профессор, заведующая кафедрой «Государственно-правовые дисциплины», Пензенский государственный университет; 440026, Российская Федерация, г. Пенза, ул. Красная, д. 40

ORCID ID: 0000-0002-4563-1725; ResearcherID: C-7120-2017; SPIN-код: 5496-7700 e-mail:pgu-gpd@yandex.ru 